\title{
Intraoperative Blood Salvage in Bacterial Contaminated Surgical Site - an in vitro Study
}

\author{
Christoph Lenzen \\ Mund-, Kiefer- und Gesichtschirurgie / Plastisch-Ästhetische Operationen, St. Josefshospital Krefeld, Germany
}

\section{Key Words}

Intraoperative autotransfusion - Cell salvage .

Orthognathic surgery - Blood loss - Bacterial elimination .

Endotoxin adsorption

\section{Summary}

Background: Cell saving and autogenic retransfusion is a well established procedure in orthopedic, cardiac and abdominal surgery. But it is contraindicated at a bacterially contaminated surgical site such as the oral cavity. Materials and Methods: In 2003 and 2004 a clinically oriented in vitro study was processed in 45 enlarged operations for dysgnathia to recycle the intraoperatively collected blood contaminated with microrganisms of the oral cavity. Cell salvage, leukocyte depletion, antimicrobial medical treatment, and a selective endotoxin adsorption were used as single cleaning procedures. Hematological, coagulative, immunologic and microbiological examinations were carried out, including the measurement of endotoxin before, during and after the procedure. In addition, the individual cleaning steps were changed in their succession to determine the most effective one. Results: Already cell salvage and leukocyte depletion could eliminate a considerable part of the oral cavity germs. However, only extracorporeal addition of antibiotic and antimycotic agents guaranteed a reproducible bacterial removal. Endotoxin could be eliminated up to $99.9 \pm 0.1 \%$ by all purification steps, including a specific endotoxin adsorber. At the end of all procedures hematocrit was increased by a renewed washing centrifugation. The hemolysis rate at the end was $0.2 \pm 0.1 \%$. Cytokines and fibrin degradation products were eliminated by more than $90 \%$. Because of the multistage purification procedure, $50 \%$ of intraoperative blood loss could be compensated. Conclusion: The combination of cell salvage, leukocyte depletion, antimicrobial medical treatment and selective endotoxin adsorption allows for the production of autogenic red blood cell concentrates free of germs, saliva and endotoxin also from a bacterially contaminated surgical site.

\section{Schlüsselwörter \\ Intraoperative Autotransfusion - Maschinelle Autotransfusion . Orthognathe Chirurgie - Blutverlust - Bakterielle Elimination . Endotoxinadsorption}

\section{Zusammenfassung}

Hintergrund: Die maschinelle Autotransfusion ist ein etabliertes Verfahren in der orthopädischen, abdominalen und Kardiochirurgie. Aber sie ist bisher noch nicht zugelassen für die Anwendung in einem bakteriell kontaminierten Operationsgebiet, z.B. der Mundhöhle. Material und Methoden: In den Jahren 2003 und 2004 haben wir an unserer Klinik eine klinisch orientierte In-vitro-Studie durchgeführt. Dabei wurde bei 45 ausgedehnten chirurgischen Eingriffen wegen Dysgnathie das mit Speichel und Bakterien der Mundhöhle kontaminierte Blut gesammelt. Mit Hilfe einer Waschzentrifugation, einer Leukozytendepletion, einer antimikrobiellen medikamentösen Behandlung sowie einer selektiven Endotoxin-Adsorption wurde das gesammelte Wundblut aufbereitet, gereinigt und zu einem autogenen Erythrozytenkonzentrat aufkonzentriert. Zur Untersuchung der Qualität wurden hämatologische und gerinnungsphysiologische, immunologische und mikrobiologische Parameter analysiert. Zusätzlich wurde die Endotoxin-Konzentration vor, während und am Ende der Aufbereitungsprozedur bestimmt. Die Reihenfolge der einzelnen Reinigungsschritte und die Häufigkeit ihres Einsatzes wurden mehrfach geändert, bis die effektivste Sequenz gefunden war. Ergebnisse: Durch den Einsatz des Cell-Savers sowie die Leukozytendepletion konnte ein beträchtlicher Anteil der gesammelten Keime der Mundhöhle eliminiert werden. Allerdings war nur durch die extrakorporale Zugabe von Antibiotika und Antimykotika eine reproduzierbare Bakterienelimination möglich. Endotoxine konnten durch die einzelnen Aufbereitungsschritte einschließlich des spezifischen Endotoxin-Adsorbers bis auf $99,9 \pm 0,1 \%$ reduziert werden. Die Hämolyserate betrug am Ende 0,2 $\pm 0,1 \%$. Zytokine und Fibrinspaltprodukte wurden zu mehr als $90 \%$ eliminiert. Die zugesetzten antimikrobiellen Substanzen wurden mit Raten zwischen $95,8 \pm 11,7 \%$ und $92,0 \pm 15,4 \%$ wieder eliminiert. Aufgrund der mehrstufigen Aufbereitungsprozedur hätte ein intraoperativer Blutsverlust von $50 \%$ kompensiert werden können. Schlussfolgerung: Durch die Kombination aus Cell-Saver, Leukozytendepletion, antimikrobieller medikamentöser Behandlung und selektiver Endotoxin-Adsorption konnte ein autogenes Erythrozytenkonzentrat aus einem bakteriell kontaminierten Operationsgebiet reproduzierbar keimfrei hergestellt werden. Endotoxine konnten bis auf einen absoluten Gehalt von $1 \pm 1 \mathrm{ng}$ eliminiert werden.

\begin{tabular}{|c|c|}
\hline KARGER & (c) 2006 S. Karger GmbH, Freiburg \\
\hline $\begin{array}{l}\text { Fax +49 } 7614520714 \\
\text { E-mail Information@Karger.de } \\
\text { www.karger.com }\end{array}$ & $\begin{array}{l}\text { Accessible online at: } \\
\text { www.karger.com/tmh }\end{array}$ \\
\hline
\end{tabular}

Dr. Dr. med. Christoph Lenzen

Mund-, Kiefer- und Gesichtschirurgie / Plastisch-Ästhetische Operationen St. Josefshospital Krefeld

Kurfürstenstraße 69, 47829 Krefeld, Germany

Tel. +49 2151-4527549, Fax -622580

E-mail dr.dr.c.lenzen@t-online.de 


\section{Introduction}

The more elective an operation, the greater is the necessity of preventing hemophilic complications. One of the most elective operations in cranio-maxillofacial surgery are surgical corrections of an inborn or acquired skeletal deformity of the upper and/or lower jaw with incongruence of the bite plane. These surgical procedures were carried out exclusively from an intraoral approach. During maxillar or mandibular orthognathic surgery unexpected, excessive blood loss may occur due to a reduced activity of individual coagulation factors or disturbances of thrombocyte function $[1,2]$.

Intra- and postoperative hemorrhagic complications may be due to thrombopathy, coagulopathy or vascular disorders. Congenital as well as acquired disorders may affect all three systems involved in coagulation. Congenital disorders of thrombocytes include the various diseases associated with thrombocytopenia and hemorrhage.

However, acquired disorders leading to excessive intraoperative blood loss are more frequent. In particular drug-induced thrombopathy resulting from administration of acetylsalicylic acid or non-steroidal antiphlogistics may bring the patient into a hemodynamically dangerous situation during or following orthognathic surgery. Acquired, drug-induced coagulopathies almost exclusively result from administration of anticoagulants, e.g. cumarine derivatives. Acquired vascular disorders are observed in vitamin $\mathrm{C}$ deficiency, dysproteinemia as well as serious infections. Prevention of coagulation complications as well as therapy of intra- or postoperative bleeding requires management on a systemic and a local level.

There are a lot of general measures to reduce intraoperative blood loss. These include acute normovolemic hemodilution, controlled hypotension, placing the patient in such a way that the head is higher than the heart region, and intensive intraoperative hemostasis which however is rather difficult in bony structures [3]. In the past few years it has been possible to avoid allogeneic blood transfusion in orthognathic surgery at the Krefeld department of maxillofacial plastic surgery by using autogenic blood donated preoperatively [17]. Under certain conditions erythropoietin was administered preoperatively, and a rather low postoperative hemocrit was also accepted $[3,4]$.

So far intraoperative autotransfusion is contraindicated in a bacterially contaminated surgical site such as oral cavity. The oral cavity of healthy individuals is contaminated with more than 700 bacterial species, i.e. a mixture of Gram-positive and Gram-negative aerobic and anaerobic germs [5], but washing centrifugation is not able to eliminate bacterial contamination totally [6]. Candida albicans is most frequently found species in the oral cavity which could be isolated of $2-71 \%$ of healthy individuals [7]. Odds [8] reported a mean colonization rate of $26 \%$ in immunocompetent individuals. Transfusion of centrifuged shed red blood cell (RBC)concentrates resulted not only in elevated cytokine levels but also in fever and transient
Table 1. Origin of coagulation restriction in 105 patients of the Department for Cranio-Maxillofacial and Plastic-Esthetic Surgery, Krefeld

\begin{tabular}{lc}
\hline Origin of coagulation restriction & Patients, \% \\
\hline Acetylsalicylic acid-induced thrombopathia & 14.3 \\
Idiopathic thrombopathia & 3.8 \\
Coagulation factor activity between 40 and $70 \%$ & 28.6 \\
Coagulation factor activity below 40\% & 2.9 \\
\hline
\end{tabular}

bacteremia involving the pathogens previously detected in centrifuged shed red blood cell concentrates $[9,10]$.

Lipopolysaccharides (LPS) being released from the cell wall of Gram-negative bacteria act as endotoxins. They are responsible for the occurrence of fever and septic symptoms. Intravenous injections of LPS lead to fever and septic symptoms as it is well known from hyperthermia therapy [11-15].

Because formerly investigations in our department have shown that a lot of the normally young and healthy patients undergoing orthognathic surgery have disorders of platelet function or reduced coagulation factor activity, it would helpful to have autogenic RBC concentrates in case of excessive intraoperative blood loss. These former tests revealed thrombocytopenia with values lower than $100,000 \times 10^{-9} / 1$ in $2.9 \%$ of the cases. In $18.1 \%$ of the cases, thromocytopathy with reduced function and thus an increased risk of intra- or postoperative bleeding was found preoperatively. The case histories revealed that in $78.9 \%$ of these patients the intake of acetylsalicylic acid at least 14 days prior to the analysis of the coagulation status caused the reduction of thrombocyte function (14.3\% of all patients). A reduced activity of coagulation factors ( $>70 \%$ of normal value) was observed in $31.4 \%$ of the patients - in $28.6 \%$ of the patients the activity of at least one coagulation factor was reduced to only $40-70 \%$, and in $2.9 \%$ of the patients the activity of one or more coagulation factors even did not reach $40 \%$ of normal values (table 1) [1]. Because investigations of the coagulation status are not included in clinical routine, unexpected bleeding complications can result and lead to a necessity of transfusion [1, 2, 16-23].

However, the transfusion of allogeneic RBC concentrates is afflicted with significant risks, e.g. transmission of HIV, HBV and $\mathrm{HCV}$ or other viruses. Also bacterial contamination, confusion of RBC concentrates, and immunomodulating effects can endanger patients receiving allogeneic transfusions during these elective operations [25-28]. Lowe [27] stated that the risk for a complication following allogeneic blood transfusion is 1:25,000 and for dead 1:100,000.Some of these dangers can be prevented by preoperative autogenic blood donation. However, secondary bacterial contamination or mix-up of blood samples may also occur in autogenic RBC concentrates [28]. Moreover, there is a considerable number of mostly female patients in whom preoperative autogenic blood donation cannot be done due to a low hemoglobin value. 


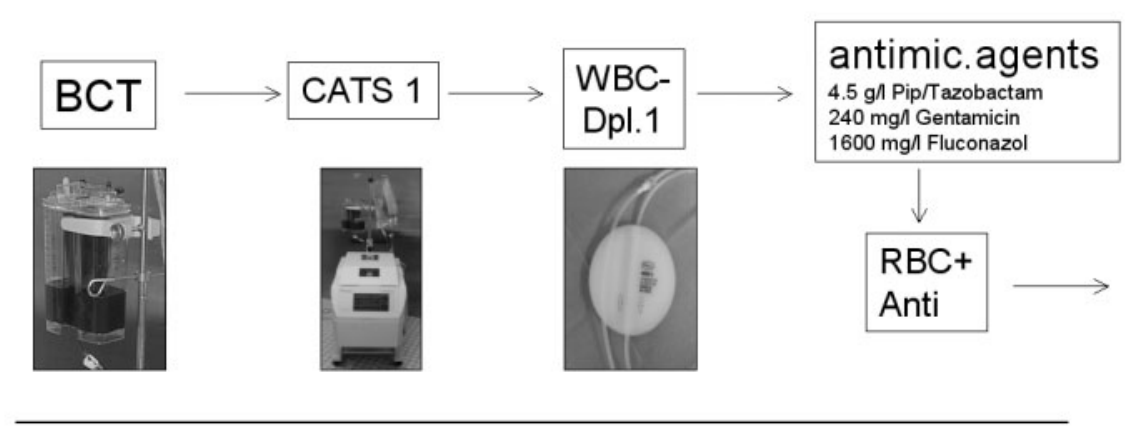

Fig. 1. Six-stage purification sequence for manufacturing a abacterial autogenic RBC concentrate from wound blood of the oral cavity.

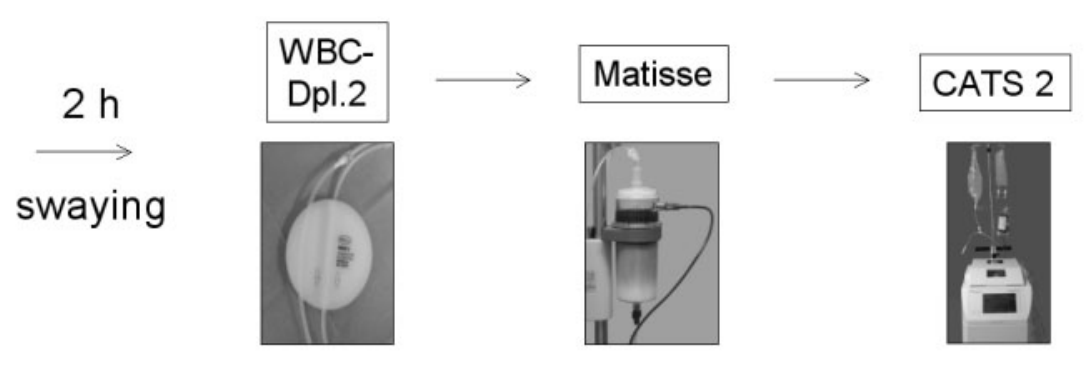

\section{Materials and Methods}

At the Department of Cranio-Maxillofacial and Plastic Surgery, Krefeld, 352 orthognathic operations of the upper and/or lower jaw were performed in the years 2003 and 2004. In 45 of these patients, blood was collected intraoperatively for analysis of microbiological contamination. All patients got an antibiotic treatment with ampicillin/sulbactam $3 \mathrm{~g}$ before starting the operation. Swaps were taken from the oral cavity at the beginning and at the end of surgery. This was performed to identify the origin of bacteria in the blood collecting trunk (BCT) later on. Furthermore, the endotoxin level of patients' blood was examined in 10 patients before operation, $1 \mathrm{~h}$ after start of the operation, at the end of operation and $24 \mathrm{~h}$ after surgery. The endotoxin detection limit was $0.00625 \mathrm{ng} / \mathrm{ml}$.

Different purification systems were used to clean the collected blood saliva mixture from microbiological contamination and endotoxin load. These systems include the cell saver System CATS ${ }^{\mathrm{TM}}$ (Fresenius AG, Bad Homburg, Germany), the leukocyte depletion filter WBF3 ${ }^{\mathrm{TM}}$ (Pall $\mathrm{GmbH}$, Dreieich, Germany), and antimicrobial addition of $4.5 \mathrm{~g} / \mathrm{l}$ piperacillin/tazobactam (Tazobac ${ }^{\mathrm{TM}}$, Wyeth Pharma GmbH, Münster, Germany), $240 \mathrm{mg} / \mathrm{l}$ gentamicin (ratiopharm GmbH, Ulm, Germany) and 1,600 mg/l fluconazol (Diflucan ${ }^{\mathrm{TM}}$, Pfizer Pharma GmbH, Karlsruhe, Germany). This combination and dosage of antimicrobial drugs has been shown to effectively eliminate germs of the oral cavity. Moreover, an endotoxin adsorber which is based on immobilized human serum albumin (iHSA) (MATISSE ${ }^{\text {TM; }}$ Fresenius AG) was used. This system was shown to efficiently remove LPS from blood during direct hemoperfusion [29].

The primary aim of this in vitro study were to eliminate the bacterial contamination and the endotoxin load of the intraoperatively collected blood. The secondary aim was to create an autogenic RBC concentrate having a hematologic quality comparable to that of allogeneic RBC concentrates. To reach this the four different single steps were combined in various orders To identify the most effective sequence, the four purification steps described above were applied in varying order. After each purification step, the following parameters were measured: hemoglobin, hematocrit, erythrocytes, leukocytes, thrombocytes, mean corpuscular volume, mean corpuscular hemoglobin, lactate dehydrogenase, D-dimer, potassium, calcium, protein, amylase, heparin, free hemoglobin, haptoglobulin, tat complex, TNF- $\alpha$, IL-1 $\beta$, IL-6, rate of hemolysis, activated complement 3 , LPS, tazobactam, piperacillin, gentamicin, fluconazol, number of germs, num- ber of Gram-positive germs, number of Gram-negative germs, number of fungi, concentration of germs.

All data, except for hemoglobin concentration, hematocrit and leukocyte concentration, were calibrated to eliminate dilution factors.

All data were documented as single measures and as means \pm standard deviation. Significance of differences was tested using Student's $t$ test, with the level of significance being defined as $\mathrm{p}<0.05$.

\section{Results}

\section{Most Effective Purification Sequence for Bacterially Contaminated Shed Blood}

With respect to the primary and secondary aims, the following order of the processing steps was shown to be the most efficient (fig. 1): First, the collected blood, contaminated with saliva of the oral cavity and saline fluid of the drill cooling system while plate fixation, was cleaned and concentrated using the cell saver system CATS. Then the persistent leukocyte concentration was reduced by a special white blood cell filter. After this, the antimicrobial agents piperacillin/tazobactam, gentamicin and fluconazol were added. To increase the antimicrobial effect, the samples were incubated for at least $2 \mathrm{~h}$ under agitation. Leukocyte depletion was performed once more to reduce remaining white blood cells with possibly phagocytized bacteria. Then, the endotoxin adsorber MATISSE was applied. Before use the endotoxin adsorber must be activated by a large volume of saline solution ( 81$)$. To compensate for dilution by the addition of antimicrobial agents endotoxin adsorber treatment and to finally get an RBC concentrate, repeated CATS application was performed.

Only with this setting, a complete bacterial elimination could be achieved. 
Table 2. Microorganisms most commonly found in the oral cavity preoperatively and postoperatively and in the BCT of 45 patients

\begin{tabular}{llll}
\hline & \multicolumn{2}{l}{ Oral cavity } & \multirow{2}{*}{ BCT } \\
\cline { 2 - 3 } & $\begin{array}{l}\text { preoper- } \\
\text { atively }\end{array}$ & $\begin{array}{l}\text { postoper- } \\
\text { atively }\end{array}$ \\
\hline C. albicans & 18 & 18 & 18 \\
Beta-hemolytic streptococci & 15 & 17 & 14 \\
Alpha-hemolytic streptococci & 11 & 8 & 6 \\
Staphylococcus aureus & 2 & 5 & 5 \\
Klebsiella pneumoniae & 5 & 3 & 5 \\
Streptococcus viridans & 5 & 3 & 3 \\
Streptococcus dysgalactiae, subsp. equisimilis & 3 & 3 & 3 \\
Hafnia alvei & 3 & 2 & 3 \\
Corynebacterium sp. & 2 & 2 & 3
\end{tabular}

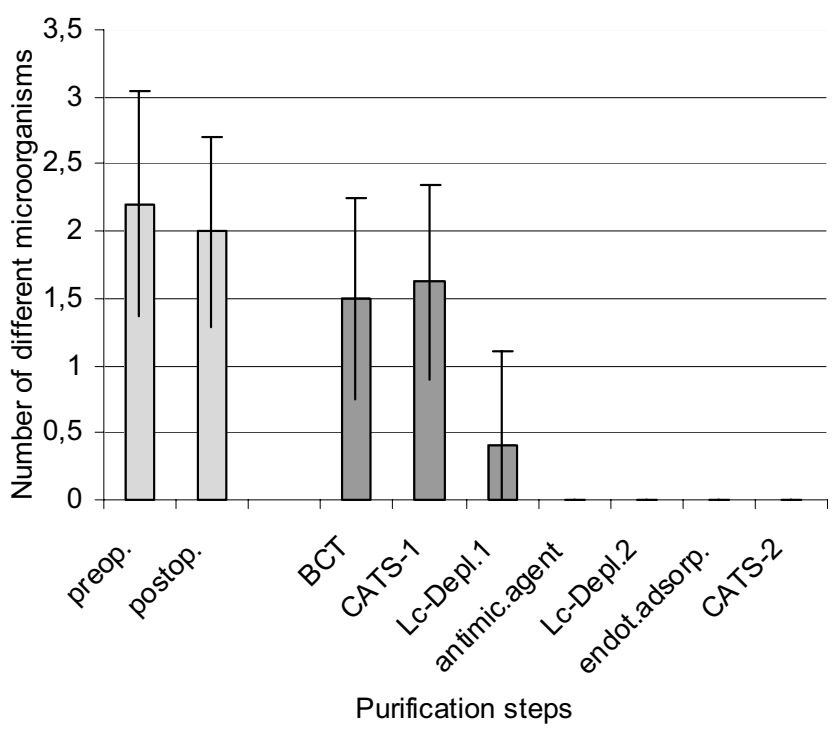

Fig. 2. Number of different detected microorganisms in each purification step.

\section{Measurements of Bacterial Reduction and Endotoxin Elimination}

The oral cavity of healthy individuals is contaminated with more than 700 Gram-positive and Gram-negative aerobic and anaerobic bacterial species [5]. However, not all are detectable because of their small count. Only bacteria above $10^{2}$ $\mathrm{CFU} / \mathrm{ml}$ (CFU = colony forming units) can be detected by standardized swaps.

In the oral cavity, we found 20 different species of microorganisms preoperatively and 18 species postoperatively. In the BCT 15 different microorganisms were still detected. The most common microorganisms were C. albicans, beta-hemolytic streptococci and alpha-hemolytic streptococci (tables $2,3)$.
Table 3. Quantity of different groups of the 25 microorganisms detected in the oral cavity preoperatively and postoperatively and in the BCT of 45 patients

\begin{tabular}{lllllr}
\hline \multirow{2}{*}{ Gram } & Form & Milieu & \multicolumn{2}{c}{ Oral cavity } & BCT \\
\cline { 4 - 5 } & & & $\begin{array}{l}\text { preoper- } \\
\text { atively }\end{array}$ & $\begin{array}{l}\text { postoper- } \\
\text { atively }\end{array}$ \\
& & & 36 & 35 & 32 \\
+ & coccus & aerobic & 36 & 2 & 3 \\
+ & bacillary & aerobic & 2 & 5 & 2 \\
- & coccus & aerobic & 8 & 12 & 14 \\
- & bacillary & aerobic & 15 & 0 & 0 \\
+ & coccus & anaerobic & 2 & 4 & 0 \\
+ & bacillary & anaerobic & 2 & 3 & 0 \\
\hline & bacillary & anaerobic & 8 & 18 & 18 \\
\hline
\end{tabular}

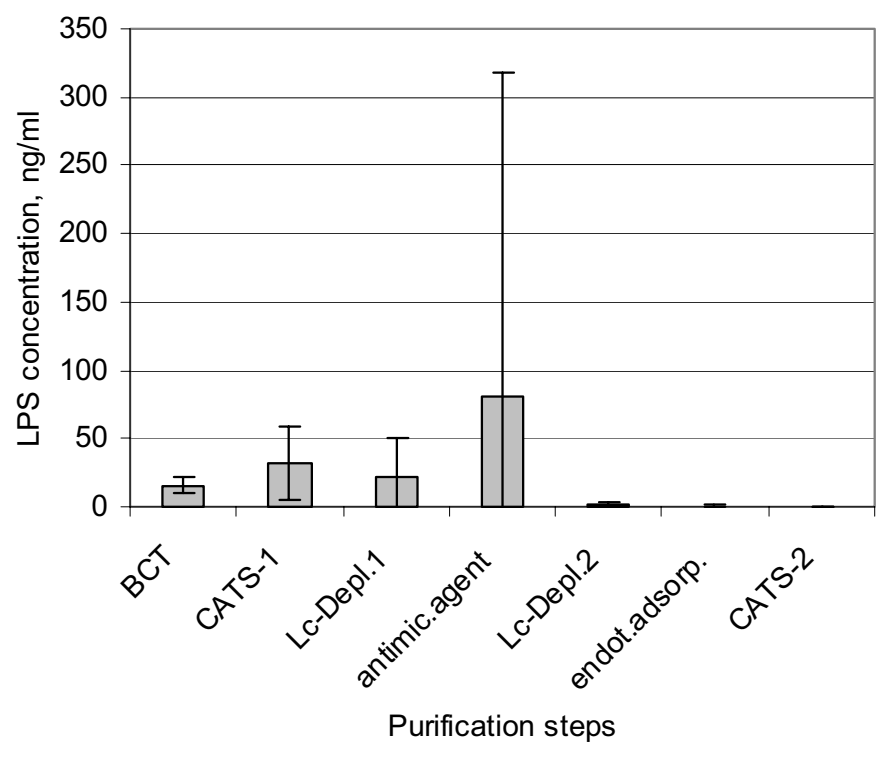

Fig. 3. Changes of the LPS concentration over the whole purification procedure.

On average we have preoperatively found $2.2 \pm 0.8$ different germs in the oral cavity of our young and healthy patients. Postoperatively $2.1 \pm 0.7$ different bacteria species were detected. Their count was more than $10^{6} / \mathrm{ml}$, independent of the intravenous antibiotic treatment at the beginning of the operation. In the BCT $1.0 \pm 0.6$ different bacterial microorganisms were found. All detected species in the BCT were also found formerly in the oral cavity. So a secondary contamination during the purification procedure was excluded. Bacterial contamination data was given in $\mathrm{CFU} / \mathrm{ml}$. In BCT we found a mean concentration of $2.8 \times 10^{4} \pm 3.3 \times 10^{4} \mathrm{CFU} / \mathrm{ml}$, with a maximum of $10^{5} \mathrm{CFU} / \mathrm{ml}$. After the first CATS application, $1.6 \pm$ 0.7 different microorganic species were identified. Their concentration was $2.6 \times 10^{4} \pm 3.3 \times 10^{4} \mathrm{CFU} / \mathrm{ml}$, with a maximum of $10^{5} \mathrm{CFU} / \mathrm{ml}$. After the first leukocyte depletion, we found 


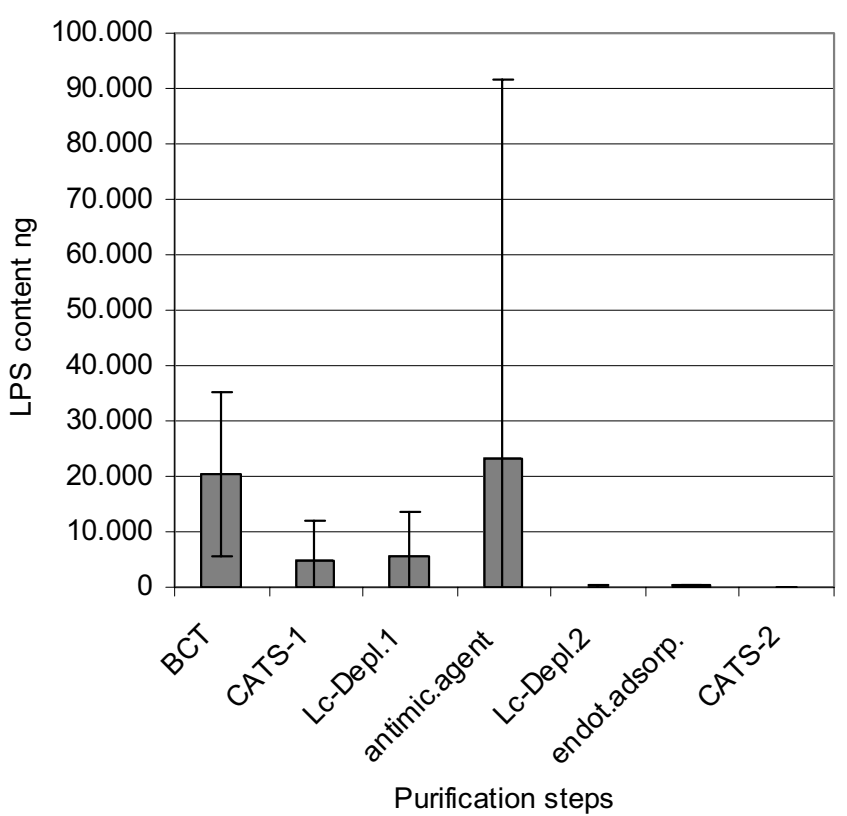

Fig. 4. Changes of the LPS content over the whole purification procedure.

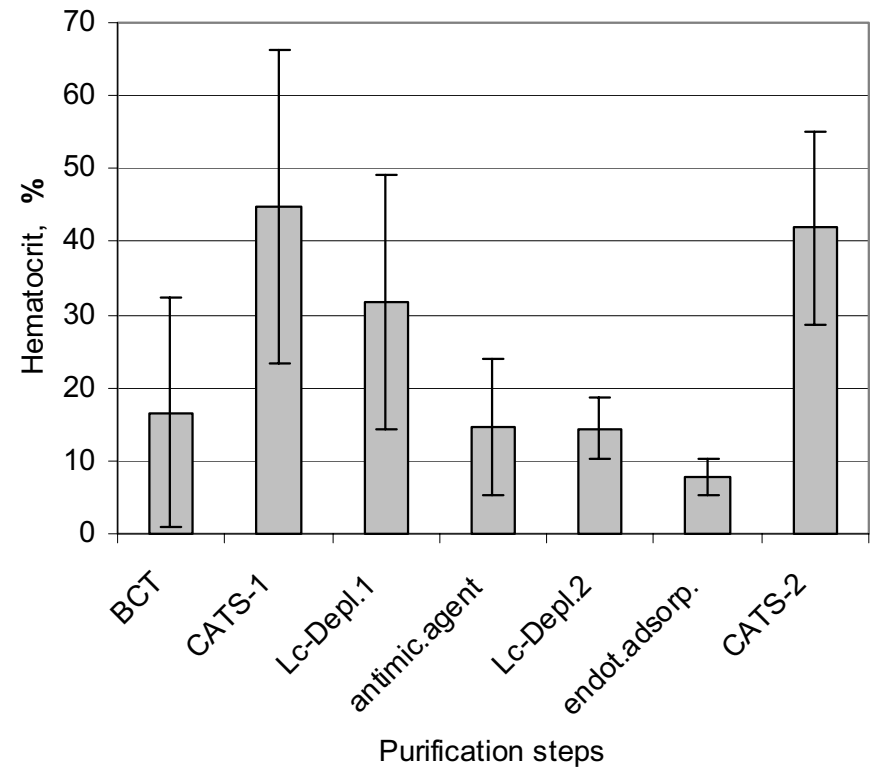

Fig. 6. Changes of the hematocrit over the whole purification procedure.

$0.4 \pm 0.7$ bacteria. Bacterial contamination decreased to $6.4 \times$ $10^{3} \pm 2.3 \times 10^{4} \mathrm{CFU} / \mathrm{ml}$, with a maximum of $10^{5} \mathrm{CFU} / \mathrm{ml}$. After application of the antimicrobial agents no bacterial contamination could be detected anymore. This means that the bacterial concentration is reduced below $10^{2} \mathrm{CFU} / \mathrm{ml}$ (fig. 2). The portions of Gram-positive and Gram-negative pathogens were similar(40 \pm 9 vs. $40 \pm 5 \%$ ). The bacterial elimination of the single steps was not significant. But we found a highly significant reduction after the addition of antibiotics with respect to the start concentration in BCT $(\mathrm{p}<0.01)$.

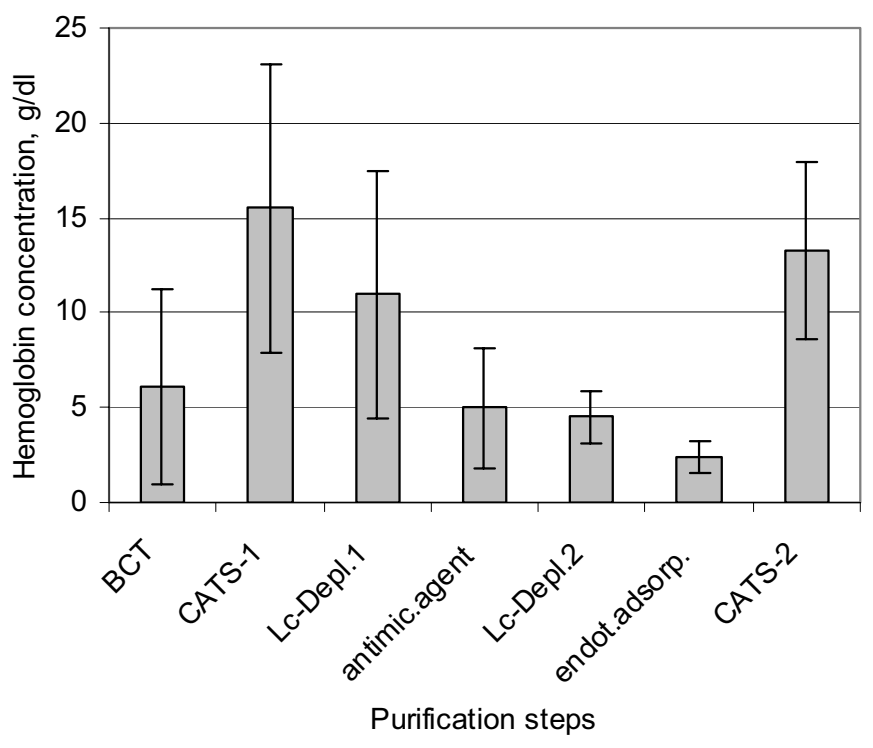

Fig. 5. Changes of the hemoglobin concentration over the whole purification procedure.

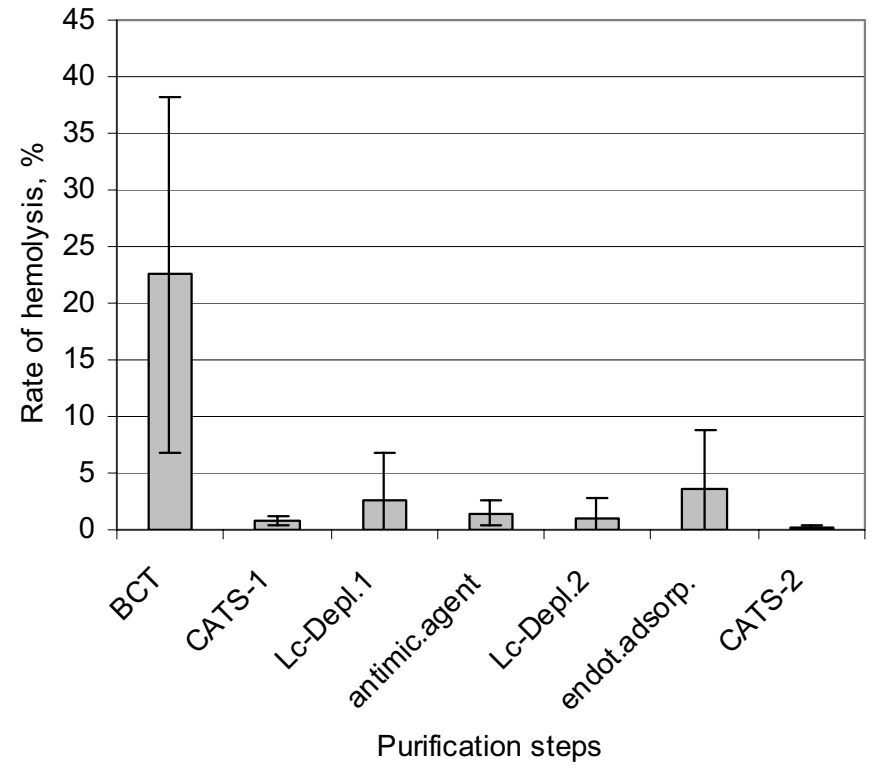

Fig. 7. Changes of the hemolysis rate over the whole purification procedure.

C. albicans was found in the oral cavity of $40 \%$ of our patients pre- and postoperatively. In $35 \%$ of our BCTs, C. albicans was found too. But in all cases it could not be detected after first leukocyte depletion and in all further purification steps. The concentration of C. albicans in BCT was $3.6 \times 10^{4} \pm 4.0 \times 10^{4}$ $\mathrm{CFU} / \mathrm{ml}, 4.0 \times 10^{4} \pm 4.5 \times 10^{4} \mathrm{CFU} / \mathrm{ml}$ after the first CATS application and $0.0 \pm 0.0 \mathrm{CFU} / \mathrm{ml}$ after the first leukocyte depletion. The maximum detected concentration of fungi was $10^{5}$ $\mathrm{CFU} / \mathrm{ml}$. 
LPS was detected in the BCT and during all further purification steps up to the final RBC concentrate in different concentrations: LPS concentration in BCT $15.6 \pm 6.3 \mathrm{ng} / \mathrm{ml}$, after the first CATS application $31.5 \pm 26.7 \mathrm{ng} / \mathrm{ml}$, after the first leukocyte depletion $22.0 \pm 26.8 \mathrm{ng} / \mathrm{ml}$, after antimicrobial treatment $81.0 \pm 237.6 \mathrm{ng} / \mathrm{ml}$, after the second leukocyte depletion $1.4 \pm 2.0 \mathrm{ng} / \mathrm{ml}$, after selective endotoxin adsorption $0.7 \pm 0.7 \mathrm{ng} / \mathrm{ml}$, and after second CATS centrifugation $0.04 \pm$ $0.05 \mathrm{ng} / \mathrm{ml}$. The final concentration of endotoxin corresponded to a total content of $1.0 \pm 1.0 \mathrm{ng}$ in the whole RBC concentrate (fig. 3, 4).

\section{Measurements of Hematological Parameters during Purification}

\section{Hemoglobin}

The hemoglobin concentration in the BCT was $5.1 \pm 6.1 \mathrm{~g} / \mathrm{dl}$ and increased to $15.5 \pm 7.6 \mathrm{~g} / \mathrm{dl}$ after the first CATS application. Leukocyte depletion reduced the hemoglobin content to $11.0 \pm 6.5 \mathrm{~g} / \mathrm{dl}$. After dilution by antimicrobial agents the hemoglobin concentration was $5.0 \pm 3.2 \mathrm{~g} / \mathrm{dl}$, after the second leukocyte depletion $4.5 \pm 1.3 \mathrm{~g} / \mathrm{dl}$, and after endotoxin adsorption $2.4 \pm 0.8 \mathrm{~g} / \mathrm{dl}$. The second CATS application increased the hemoglobin content again to $13.3 \pm 4.6 \mathrm{~g} / \mathrm{dl}$. The hemoglobin contents in the BCT and after second CATS are significantly different $(\mathrm{p}<0.05)$ (fig. 5).

\section{Hematocrit}

Hematocrit was measured in BCT as $16.5 \pm 15.7 \%$. It increased by the different cleaning steps up to $41.9 \pm 13.2 \%$ at the end of all procedures $(p<0.01)$. The hematocrit of the final product is nearly as high as that of allogeneic or preoperatively stored autogenic RBC concentrates (fig. 6).

\section{Hemolysis}

In $\mathrm{BCT}$ the rate of hemolysis was $22.6 \pm 15.7 \%$, but after the whole purification it was reduced to $0.2 \pm 0.1 \%$, being far below the legitimate limit of hemolysis $(0.8 \%)$ in allogeneic RBC concentrates (fig. 7).

\section{Free Hemoglobin}

Free hemoglobin is a marker for destruction of RBCs. In BCT the free hemoglobin concentration was $1,061.2 \pm 563.7 \mathrm{mg} / \mathrm{dl}$. After the first CATS application it was reduced to $379.8 \pm$ $223.2 \mathrm{mg} / \mathrm{dl}$. Dual application of leukocyte depletion, antimicrobial treatment, and endotoxin adsorption only marginally affects free hemoglobin. After final CATS washing a free hemoglobin concentration of $77.8 \pm 34.3 \mathrm{mg} / \mathrm{dl}$ was measured. A highly significant reduction of free hemoglobin of the whole purification process was found when comparing free hemoglobin in BCT and in the final RBC concentrate $(\mathrm{p}<0.01)$, and the elimination rate amounts to $92.7 \%$ (fig. 8 ).

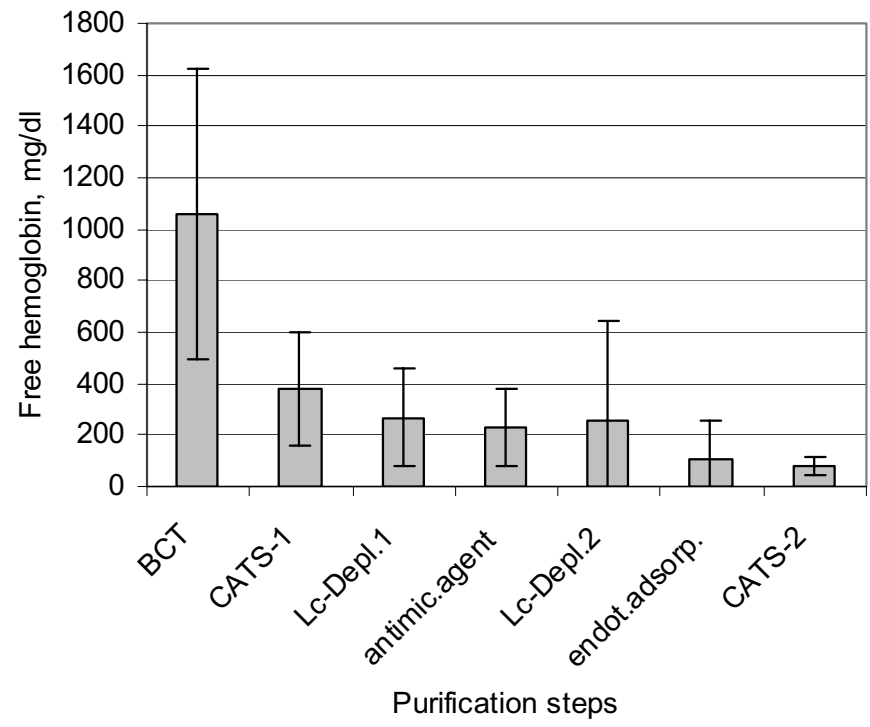

Fig. 8. Changes of the free hemoglobin concentration over the whole purification procedure.

\section{Leukocytes}

The leukocyte concentration in BCT was $1.3 \pm 0.7 \times 10^{9} / 1$. After CATS it amounts to $3.4 \pm 1.8 \times 10^{9} / 1$. With the first white blood cell filter reduction to $0.3 \pm 0.9 \times 10^{9} / 1$ was achieved. After dilution with antimicrobial agents we found a leukocyte concentration of $0.05 \pm 0.1 \times 10^{9} / 1$ and after the second leukocyte depletion of $0.08 \pm 0.1 \times 10^{9} / 1$. Endotoxin adsorption did not change the leukocyte concentration. After final CATS treatment a leukocyte concentration of $0.12 \pm 0.1 \times 10^{9} / 1$ was measurable. None of the changes was significant.

\section{Cytokines}

The following cytokines were measured: TNF- $\alpha$, IL-1 $\beta$, and IL-6. In BCT the concentrations of TNF- $\alpha$, IL-1 $\beta$ and IL-6 were $143.5 \pm 261.0 \mathrm{pg} / \mathrm{ml}, 574.3 \pm 1,551.9 \mathrm{pg} / \mathrm{ml}$ and $668.6 \pm$ $1,316.4 \mathrm{pg} / \mathrm{ml}$, respectively. At the end of the purification the concentrations of TNF- $\alpha$, IL- $1 \beta$ and IL- 6 were found to be $1.0 \pm 2.3 \mathrm{pg} / \mathrm{ml}, 1.2 \pm 2.6 \mathrm{pg} / \mathrm{ml}$ and $0.7 \mathrm{pg} / \mathrm{ml} \pm 1.0 \mathrm{pg} / \mathrm{ml}$, respectively. These reductions of cytokine concentration during purification are only tendencies without any significance, presumably because of the high standard deviations (fig. 9).

\section{Potassium}

Potassium is found extracellularly in a concentration of 3.0-5.5 $\mathrm{mmol} / \mathrm{l}$. An increase of the potassium concentration is a marker for mechanical injury of RBCs during washing. In BCT the potassium concentration was $8.0 \pm 4.0 \mathrm{mmol} / \mathrm{l}$, after antimicrobial agent addition $4.1 \pm 2.9 \mathrm{mmol} / \mathrm{l}$, and after second CATS application $0.6 \pm 0.2 \mathrm{mmol} / \mathrm{l}$. The reduction of potassium between start and end of the cleaning sequence was highly significant $(\mathrm{p}<0.01)$. The elimination rate was $92.1 \%$ (fig. 10 ). 


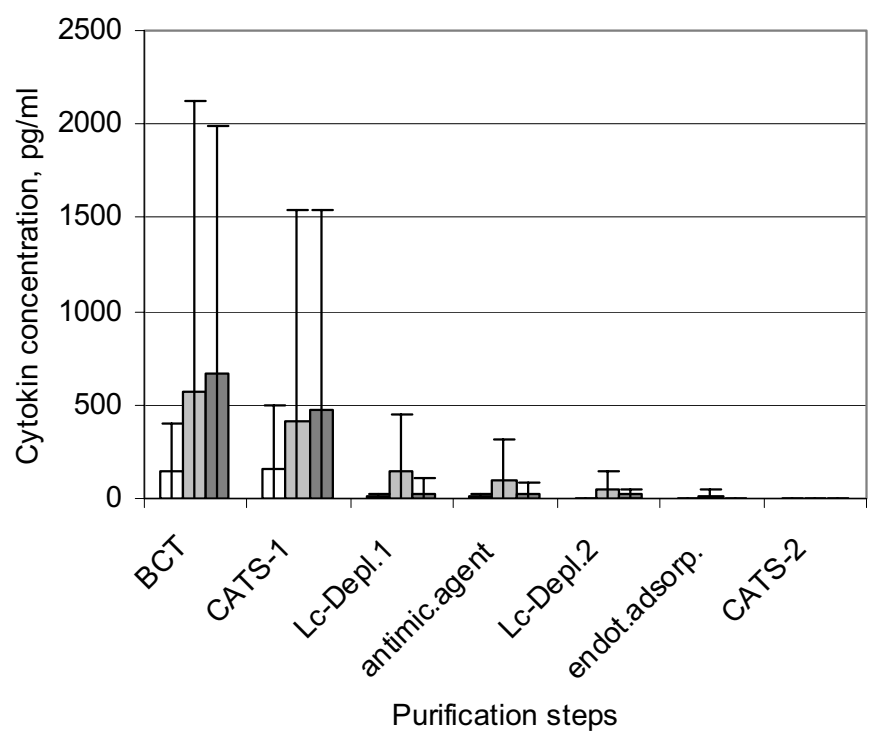

$\square$ TNF- $\alpha \square \mathrm{IL}-1 ß \square \mathrm{IL}-6$

Fig. 9. Changes of the concentrations of TNF- $\alpha$, IL- $1 \beta$ und IL- 6 over the whole purification procedure.

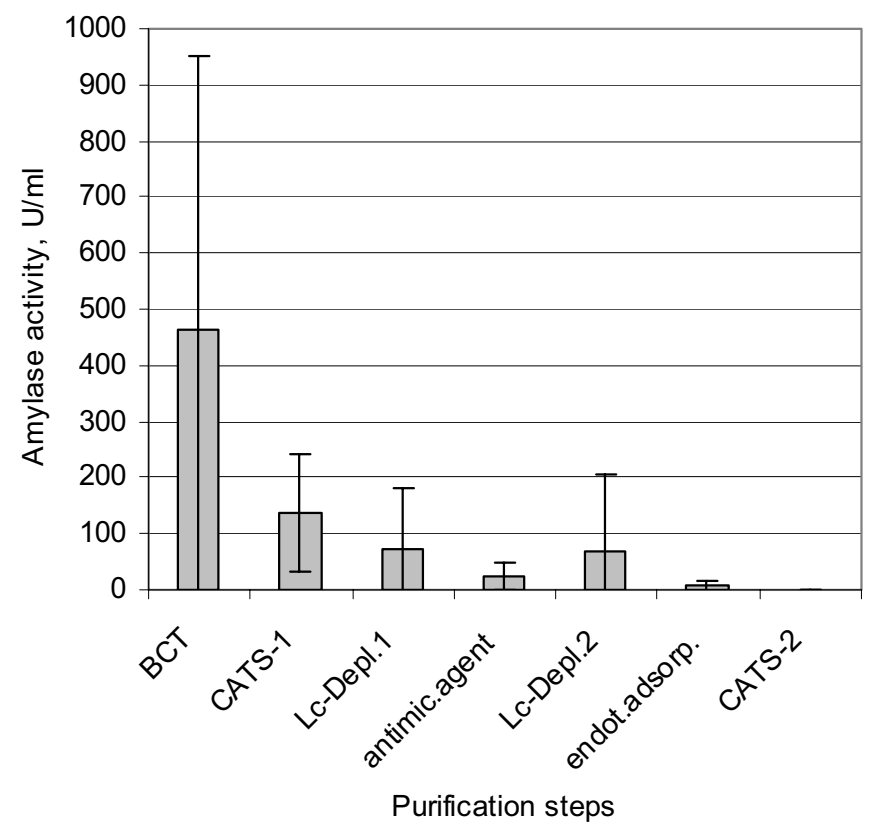

Fig. 11. Changes of the amylase activity over the whole purification procedure.

\section{Amylase}

Amylase is an enzyme of oral saliva and blood serum. Its activity in blood is smaller than $0.100 \mathrm{U} / \mathrm{ml}$ but in saliva it ranges between 5 and about $700 \mathrm{U} / \mathrm{ml}$. After collecting blood and saliva of the oral cavity, we found an activity of amylase of $463.3 \pm 473.5 \mathrm{U} / \mathrm{ml}$. After the first CATS washing $137.3 \pm 103.4$ $\mathrm{U} / \mathrm{ml}$ were remaining. Leukocyte depletion led to a reduction

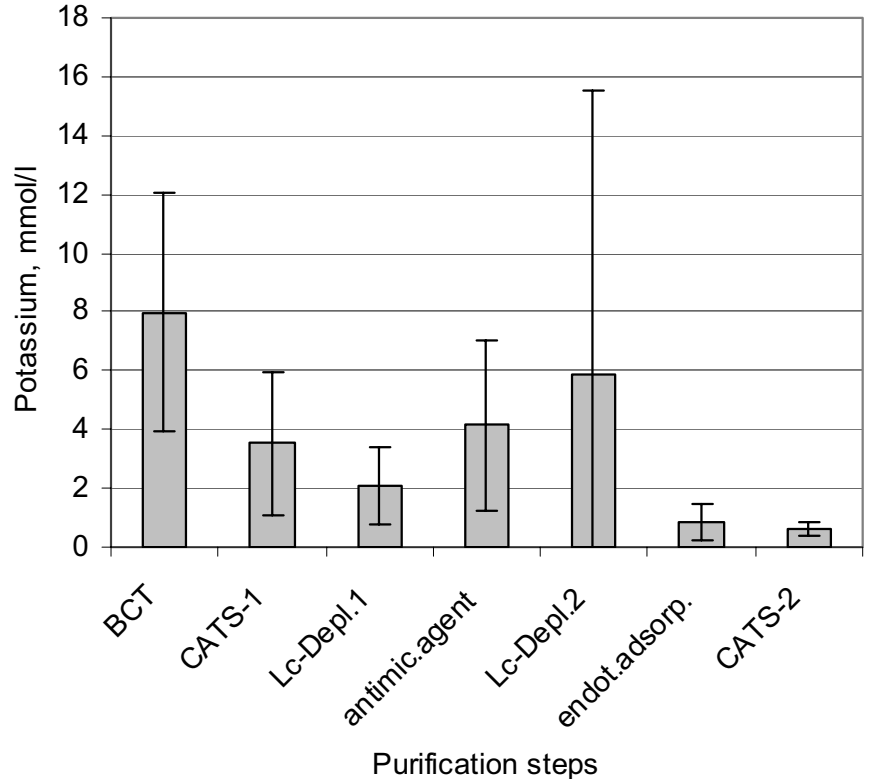

Fig. 10. Changes of the potassium concentration over the whole purification procedure.

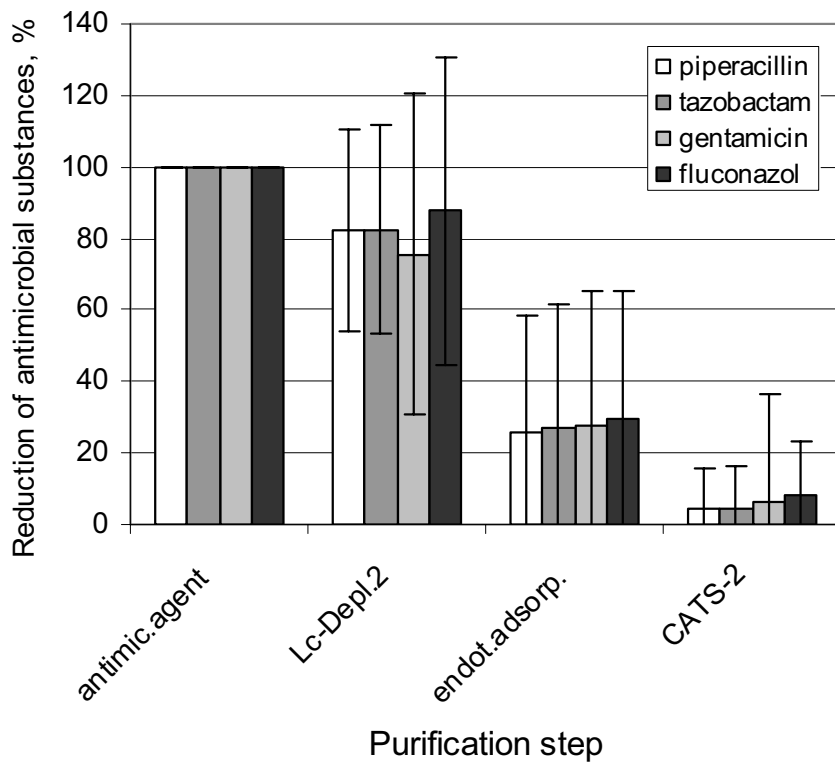

Fig. 12. Percentage elimination of piperacillin, tazobactam, gentamicin and fuconazol during further processing in the six-stage purification procedure.

to $72.0 \pm 108.0 \mathrm{U} / \mathrm{ml}$. The addition of antimicrobial agents further reduced amylase activity to $24.2 \pm 22.9 \mathrm{U} / \mathrm{ml}$. After the second white blood cell filter it was $70.4 \pm 136.9 \mathrm{U} / \mathrm{ml}$. Endotoxin adsorption decreased amylase activity to $6.3 \pm 11.2 \mathrm{U} / \mathrm{ml}$. After second CATS we could not detect any amylase activity. The difference between the first and the last value $(\mathrm{p}<0.01)$ was highly significant (fig. 11). 


\section{Mean Corpuscular Volume}

In all 6 steps of the purification sequence the mean corpuscular volume (MCV) of the erythrocytes increases. In BCT we found an MCV of $79.2 \pm 14.5 \mu \mathrm{m}^{3}$ and at the end an MCV of $91.1 \pm 3.9 \mu \mathrm{m}^{3}$. All measures are in the physiological range.

\section{Reduction of the Utilized Antimicrobial Substances}

During the addition of piperacillin/tazobactam, gentamicin and fluconazol final concentrations of $4.5 \mathrm{~g} / \mathrm{l}, 240 \mathrm{mg} / \mathrm{l}$ and $1.6 \mathrm{~g} / \mathrm{l}$, respectively, were striven. However, since the initial volumes only could be estimated, the initial concentration measured afterwards was put as a $100 \%$ standard. After leukocyte filtration, endotoxin adsorption and centrifugation by CATS, the final concentrations of piperacillin, tazobactam, gentamicin and fluconazol amounted to $4.2 \pm 11.7 \%, 4.7 \pm$ $11.6 \%, 6.6 \pm 30.1 \%$ and $8.0 \pm 15.4 \%$, respectively. Thus, the added antimicrobial drugs could be substantially reduced but not eliminated during further processing (fig. 12).

\section{Qualitative Analysis of the Fibrin Degradation Products}

The splitting of cross-linked fibrin molecules result in so called fibrin degradation products (FDP) which can be found intravasally if coagulation takes place. Their extracorporeal presence indicates that the coagulation cascade was activated. In the present study FDP proof was done only qualitatively. FDP were found in $96.7 \pm 7.6 \%$ of the samples of the BCT. After the first CATS $86.7 \pm 22.5 \%$ were detected FDP-positive. First leukocyte depletion reduced FDP to $76.7 \pm 34.6 \%$. After addition of antimicrobial agents, FDP were found in $80.0 \pm 28.8 \%$ of the samples. After the second leukocyte depletion FDP were detectable in only $10.0 \pm 22.7 \%$ and after endotoxin adsorption in $40.0 \pm 38.9 \%$ of the samples. After the final CATS, FDP could be found in $6.3 \pm 7.6 \%$ of the samples.

\section{Measurements of the Perioperative Endotoxin Level in Patients' Blood}

Because open blood vessels of soft tissue and bony structures of the oral surgical site had contact to bacteria of the oral cavity we measured in 10 patients the inner endotoxin blood level before operation, $1 \mathrm{~h}$ after start of the operation, at the end of operation, and $24 \mathrm{~h}$ after surgery. In neither of the patients endotoxin could be detected in the blood, indicating that the endotoxin concentration remains below $0.00625 \mathrm{ng} / \mathrm{ml}$ over the whole examination period.

\section{Discussion}

Retransfusion of an autogenic RBC concentrate which is produced by intraoperative cell salvage is contraindicated in bacterially contaminated surgical site. To produce an abacterial autogenic RBC concentrate from blood collected at such a contaminated site (oral cavity), we developed a six-stage processing sequence including four different cleaning and purification procedures. Using this method, the initially very high bacterial concentration could reliably be reduced to at least $10^{2} \mathrm{CFU} / \mathrm{ml}$ (detection limit in this study), resulting in an autogenic RBC concentrate suitable for retransfusion intra- or postoperatively.

In 2001, the German subdivision 'Microbiological Investigations in Transfusion Medicine' of the Study Group 'Blood' (Arbeitskreis Blut) has found a bacterial contamination in $0.22 \%$ of preoperatively donated autogenic and in $0.13 \%$ of allogeneic RBC concentrates [28].

A remaining minor bacterial contamination in our autogenic $\mathrm{RBC}$ concentrates would be eliminated by routine perioperative antibiotic prophylaxis using $2 \times 3 \mathrm{~g} /$ day ampicillin/sulbactam, which is given just before operation until the 3 rd postoperative day. Furthermore, residual concentrations of the antibiotics piperacillin/tazobactam, gentamicin and fluconazol which had been added in vitro during the manufacturing process were also present in the RBC concentrates. Thus, the risk of bacterial contamination by retransfusion of these RBC concentrates should be very low. In a study done by Locher et al. [9] to investigate the use of the Cell Saver in transoral maxillofacial surgery described the estimated total number of inoculated bacteria retransfused was between $10^{5}$ and more than $10^{7}$, resulting in an increase of body temperature to more than $39^{\circ} \mathrm{C}$ in all patients.

The endotoxin load was reduced in our study from 15.6 to $0.04 \mathrm{ng} / \mathrm{ml}$ on average. This corresponded to an absolute content of $1.0 \pm 1.0 \mathrm{ng}$. Intravenous injection of LPS is a well established procedure in active hyperthermia therapy $[1,11]$. In hyperthermia therapy, 2-4 mg LPS will be infused to increase the body temperature. e.g. in cancer therapy [9]. Rohling et al. [10] showed that retransfusion of RBC concentrates produced from blood of the oral cavity leads to an increase of interleukin and to bacteremia. According to our investigations after the first CATS application, an LPS content of $32.6 \pm 16.6 \mathrm{mg}$ has to be assumed in the retransfused $\mathrm{RBC}$ concentrates of this study. In our study the amount of retransfused LPS could be reduced to $1.0 \pm 1.0 \mathrm{ng}(0.03 \%)$. Examination of LPS in the patients' blood did not show any detectable endotoxin perioperatively. However, the detection limit for LPS is $0.00625 \mathrm{ng} / \mathrm{ml}$. If this would circulate in 51 total blood volume of a $70 \mathrm{~kg}$ patient, $31.25 \mathrm{ng}$ would be undiscovered. An endotoxin load below the detection limit represents is regarded as safe. Animal experiments have shown that injection of $0.002 \mu \mathrm{g} / \mathrm{kg}$ leads to an increase of body temperature, but changes in pulmonary arterial pressure, pulmonary vascular resistance, plasma thromboxane B2, and circulating leukocyte concentration occurs even after injection of $0.02 \mu \mathrm{g} / \mathrm{kg}$ [15].

Also the provable little residual concentrations of TNF- $\alpha$, IL- $1 \beta$ and IL- 6 which merely indicate a terminated activation of the immune system have pharmacologically and immunologically to be classified as quite safe [30-35]. 
Our autogenic RBC concentrates produced from wound blood of the oral cavity largely fulfilled the criteria for intraoperative autotransfusion described by Hansen et al. [36]. The rate of plasma elimination, measured via activity of amylase and $\mathrm{LDH}$ and via concentration of cytokines, potassium and free hemoglobin, amounted to at least $92 \%$.

The laborious production of autogenic RBC concentrates out of bacterially contaminated wound blood could only compensate $50 \%$ of the blood loss at the utmost. However, in hemodynamically critical situations of blood loss short-term available autogenic RBC concentrates could prevent lifethreatening conditions and should be preferred to allogeneic transfusions in elective surgery. The method described here should provide autogenic blood also in cases of unexpected excessive blood loss during elective surgery at a bacterially contaminated surgical site. Thus, also in these cases the risks associated with transfusion of allogeneic RBC concentrates, e.g. HIV, HBV and HCV transmission, induction of immunomodulatory effects and possibly also bacterial contamination, might be avoided. Former investigations have shown that there is a considerable number of patients with preoperatively undiscovered restricted thrombocyte function and coagulation factor activity. Such patients are endangered for excessive blood loss during orthognathic surgery [1]. Perioperative blood salvage might further reduce the consumption of allogeneic blood in these patients as well as in patients (mostly females) who are not able to preoperatively donate blood due to their low hemoglobin value $(<11 \mathrm{~g} / \mathrm{dl})$.
The autogenic RBC concentrates manufactured according to the method described here meet the quality standards of the guidelines for transfusion and hemotherapy [37] even though their average final hematocrit $(41.9 \%)$ is lower than that of allogeneic or preoperatively stored autogenic RBC concentrates. However, applying this method, risks and costs associated with the production of allogeneic or preoperatively stored autogenic RBC concentrates could be avoided.

\section{Conclusion}

Using the multistage purification procedure described above, wound blood of the oral cavity could be utilized to produce autogenic RBC concentrates fulfilling the actual quality criteria with respect to elimination of bacterial contamination and endotoxins. The hematological quality of the so obtained blood product is comparable with that of other autogenic $\mathrm{RBC}$ concentrates, which are produced in the context of the established intraoperative autotransfusion in orthopedic, abdominal and cardiac surgery. The retransfusion of these autogenic RBC concentrates can therefore be considered safe.

\section{Acknowledgement}

This study was supported by Fresenius AG, Bad Homburg, Germany, Whyeth Pharma GmbH, Munster, Germany, and Pfizer Pharma GmbH, Karlsruhe, Germany.

\section{References}

1 Lenzen C, Trobisch H, Loch D, Bull HG: Significance of hemodynamic parameters of blood loss in orthognathic surgery. Mund Kiefer Gesichtschir 1999;3(6):314-9.

2 Panula K, Finne K, Oikarinen K: Incidence of complications and problems related to orthognathic surgery: a review of 655 patients. J Oral Maxillofac Surg 2001;59(10):1128-36,discussion 1137.

$\checkmark 3$ Rohling RG, Zimmermann AP, Biro P, Haers PE, Sailer HF: Alternative methods for reduction of blood loss during elective orthognathic surgery. Int J Adult Orthodon Orthognath Surg 1999;14(1): $77-82$.

4 Rohling RG, Haers PE, Zimmermann AP, Schanz U, Marquetand R, Sailer HF: Multimodal strategy for reduction of homologous transfusions in craniomaxillofacial surgery. Int J Oral Maxillofac Surg 1999;28(2):137-42.

$\checkmark 5$ Aas JA, Paster BJ, Stokes LN, Olsen I, Dewhirst FE: Defining the normal bacterial flora of the oral cavity. J Clin Microbiol 2005;43(11):5721-32.

6 6 Boudreaux JP, Bornside GH, Cohn I Jr: Emergency autotransfusion: partial cleansing of bacteria-laden blood by cell washing. J Trauma 1983;23(1):31-5.

7 Odds FC: Candida and Candidosis. A Review and Bibliography. London, Bailliere and Tindcell, 1988

8 Odds FC: Candida infections: an overview. Crit Rev Microbiol 1987;15:1-5

9 Locher MC, Sailer HF: The use of the Cell Saver in transoral maxillofacial surgery: a preliminary report. J Craniomaxillofac Surg 1992;20(1):14-7.
10 Rohling RG, Zimmermann AP, Zellweger R, Schanz U: Transfusion of washed and centrifuged shed RBCs during maxillofacial surgery affects cytokine concentrations. Transfusion 2000;40(11): 1352-6.

11 Eskay RL, Grino M, Chen HT: Interleukins, signal transduction, and the immune system-mediated stress response. Adv Exp Med Biol 1990;274: 331-43.

12 Galanos C, Luderitz O, Westphal O: Preparation and properties of a standardized lipopolysaccharide from salmonella abortus equi (Novo-Pyrexal). Zentralbl Bakteriol [Orig A] 1979;243(2-3):226-44.

13 Heumann D, Roger T: Initial responses to endotoxins and Gram-negative bacteria. Clin Chim Acta 2002;323(1-2):59-72.

14 Opal SM: The clinical relevance of endotoxin in human sepsis: a critical analysis. J Endotoxin Res 2002;8(6):473-6.

15 Whyte RI, Warren HS, Greene E, Glennon ML, Robinson DR, Zapol WM: Tolerance to low-dose endotoxin in awake sheep. J Appl Physiol 1989;66 (6):2546-52.

16 Christiansen RL, Soudah HP: Disseminated intravascular coagulation following orthognathic surgery. Int J Adult Orthodon Orthognath Surg 1993;8(3):217-24

17 Felfernig-Boehm D, Salat A, Kinstner C, Fleck T, Felfernig M, Kimberger O, Andel H, Mueller MR: Influence of hypotensive and normotensive anesthesia on platelet aggregability and hemostatic markers in orthognathic surgery. Thromb Res 2001; 103(3):185-92.
8 Gong SG, Krishnan V, Waack D: Blood transfusions in bimaxillary orthognathic surgery: are they necessary? Int J Adult Orthodon Orthognath Surg 2002;17(4):314-7.

19 Lanigan DT, Hey JH, West RA: Major vascular complications of orthognathic surgery: hemorrhage associated with Le Fort I osteotomies. J Oral Maxillofac Surg 1990;48(6):561-73.

20 Moenning JE, Bussard DA, Lapp TH, Garrison BT: Average blood loss and the risk of requiring perioperative blood transfusion in 506 orthognathic surgical procedures. J Oral Maxillofac Surg 1995;53 (8):880-3.

21 Praveen K, Narayanan V, Muthusekhar MR, Baig MF: Hypotensive anaesthesia and blood loss in orthognathic surgery: a clinical study. Br J Oral Maxillofac Surg 2001;39(2):138-40.

22 Puelacher W, Hinteregger G, Nussbaumer W, Braito I, Waldhart E: Preoperative autologous blood donation in orthognathic surgery: a followup study of 179 patients. J Craniomaxillofac Surg 1998;26(2):121-5.

23 Samman N, Cheung LK, Tong AC, Tideman H: Blood loss and transfusion requirements in orthognatic surgery. J Oral Maxillofac Surg 1996;54(1): 21-4, discussion 25-6.

24 Umstadt HE, Weippert-Kretschmer M, Austermann KH, Kretschmer V: Need for transfusions in orthognathic surgery. No general indication for preoperative autologous blood donation. Mund Kiefer Gesichtschir 2000;4(4):228-33. 
25 Depcik-Smith ND, Hay SN, Brecher ME: Bacterial contamination of blood products: factors, options, and insights. J Clin Apheresis 2001;16(4):192-201.

26 Domen RE: Adverse reactions associated with autologous blood transfusion: evaluation and incidence at a large academic hospital. Transfusion 1998;38(3):296-300

27 Lowe E: Serious hazards of transfusion. UK hemovigilance experience and other European systems. Transfus Altern Transfus Med 2003;5(suppl 1):6-13.

28 Walther-Wenke G, Pollmeier A, Horstmann E, Bocker W: Outcome quality in terms of product safety in preoperative autologous blood donation. Anästhesiol Intensivmed Notfallmed Schmerzther 2004;39(9):559-65.

29 Zimmermann M, Busch K, Kuhn S, Zeppezauer M: Endotoxin adsorbent based on immobilised human serum albumin. Clin Chem Lab Med 1999 37(3): 373-379.
30 Amand T, Pincemail J, Blaffart F, Larbuisson R, Limet R, Defraigne JO: Levels of inflammatory markers in the blood processed by autotransfusion devices during cardiac surgery associated with cardiopulmonary bypass circuit. Perfusion 2002;17(2): 117-23.

31 Jacobi K, Walther A, Kuhn R, Dworak O, Neidhardt B, Rugheimer E: Advantages and limitations of intraoperative mechanical autotransfusion in al prostatectomies. Anaesthesist 1997;46(2):101-7.

32 Jeng JC, Boyd TM, Jablonski KA, Harviel JD, Jordan $\mathrm{MH}$ : Intraoperative blood salvage in excisional burn surgery: an analysis of yield, bacteriology, and inflammatory mediators. J Burn Care Rehabil 1998; 19(4):305-11.

33 Lin TY, Chen Y, Chiu KM, Lu CW, Jean WH, Horng FM, Chu SH: Cell Saver does not increase pro-inflammatory cytokine levels and expression of adhesive molecules in the salvaged blood of patients undergoing off-pump coronary artery bypass surgery. Acta Anaesthesiol Taiwan 2005;43(4): $211-5$.
34 Schmidt H, Bendtzen K, Mortensen PE: The inflammatory cytokine response after autotransfusion of shed mediastinal blood. Acta Anaesthesiol Scand 1998;42(5):558-64.

35 Svenmarker S, Engstrom KG: The inflammatory response to recycled pericardial suction blood and the influence of cell-saving. Scand Cardiovasc J 2003;37(3):158-64

36 Hansen E, Bechmann V, Altmeppen J, Wille J, Roth G: Quality assurance in blood salvage and variables affecting quality. Anästhesiol Intensivmed Notfallmed Schmerzther 2004;39(9):569-75.

37 Richtlinien zur Gewinnung von Blut und Blutbestandteilen und zur Anwendung von Blutprodukten (Hämotherapie) der Bundesärztekammer in der Fassung vom 04.08.2005. Bundesanzeiger 209a/ 2005. 